\title{
Micromechanical properties of longitudinally compressed wood
}

\author{
Mátyás Báder ${ }^{1}\left[\right.$ ] Róbert Németh ${ }^{1}\left([) \cdot\right.$ Johannes Konnerth $^{2}$ (])
}

Received: 24 April 2018 / Published online: 19 February 2019

(C) The Author(s) 2019

\begin{abstract}
Longitudinal compression induces changes in wood tissue resulting in better bendability. The main purpose of the present study is to identify the changes occurring at the microscopic level. Air-dried oak wood samples (Quercus petraea (Matt.) Liebl.) exposed to a thermo-hydro-mechanical treatment—combined with different longitudinal compression and relaxation treatments-were subjected to micromechanical (nanoindentation) and ultrastructural (scanning electron microscopy, atomic force microscopy) analyses at the wood cell wall level. The comparison of the various methods of treatments shows that the secondary cell wall S2 hardness decreased by $6 \%$ as a result of the compression and by $12 \%$, when combined with a long relaxation period. Cell wall indentation modulus decreased by $25 \%$ and $51 \%$, respectively. Relative elastic deformation work increased at the expense of plastic deformation work, while the relative proportion of viscoelastic work remained unchanged. Atomic force microscopic images revealed distinct disorientation of the normally straight microfibrils as a result of longitudinal compression, which was attributed to cause the weakening of the cell wall. The results indicate that changes at the ultra-structural level of the wood cell wall contributed to the changes in the macromechanical properties (for example modulus of elasticity and bendability) already reported previously, of the treated wood samples.
\end{abstract}

\section{Introduction}

As a fibrous composite, wood is well-known for its good strength to weight ratio compared to other materials (Ashby 2005) and it is characterized to be hierarchically organized. The exceptional mechanical properties are due to a functional adaptation of the structure at all levels of hierarchy (Fratzl and Weinkamer 2007). Wood cells are commonly elongated. Mechanically, the support cells (tracheids and fibres) are the most important ones, which are mainly axially oriented along the stem. In the sapwood, the trachea or vessel cells are active in water and nutrition conduction. Heartwood is a physiologically dead tissue, exhibiting a higher concentration of extractives, which significantly improve properties at most of the wood species, such as durability. In each annual ring, the cells, usually forming in the spring

Mátyás Báder

bader.matyas@uni-sopron.hu

1 Institute of Wood Science, University of Sopron, Simonyi Károly Faculty of Engineering, Wood Sciences and Applied Arts, Bajcsy-Zsilinszky Str. 4, Sopron 9400, Hungary

2 Institute of Wood Technology and Renewable Materials, BOKU-University of Natural Resources and Life Sciences Vienna, Konrad Lorenz Str. 24, 3430 Tulln an der Donau, Austria period of active growth, constitute the earlywood, while the cells arising towards the end of the season form the latewood section (Butterfield et al. 1997). In the latewood, the volume of the fibres exceeds that of the earlywood, therefore this part significantly contributes to the mechanical properties of the wood (Silva and Kyriakides 2007).

The main components of wood material are cellulose, hemicelluloses and lignin. Long but slender crystalline chains, with a length of 4-5 $\mu \mathrm{m}$, are composed of cellulose molecules (Tamer and Fauziah 2013). Cellulose molecules are arranged in bunches, called microfibrils. These are responsible for the structural properties of the wood. Hemicelluloses and lignin can be defined as the matrix of this natural composite material. These three main constituents construct the tubular microstructure of cells (Silva and Kyriakides 2007). The cells are cemented by the middle lamella (ML), which is a highly lignified part of the wood structure and has high shear strength (Dinwoodie 1971). The wood cell walls are multilayered. The fibres' thickest inner layer is called secondary wall (S2) and makes up to $85 \%$ of the cell wall's total thickness. $\mathrm{S} 2$ is considered as a highly anisotropic layer consisting of microfibrils with a single orientation that is typically between $10^{\circ}$ and $30^{\circ}$ related to the axes of the fiber, called microfibril angle (MFA). The axial 
stiffness of the cells is mainly determined by the wall thickness and the MFA (Silva and Kyriakides 2007).

The same as various other polymers, wood is characterized by viscoelastic behavior, i.e., in addition to elastic deformation, further changes also occur with loading time (Niemz 1993). In this respect, the behavior of wood differs depending on loading speed and loading direction, making it ductile in some cases and brittle in others (Matti 2014). Wood can be defined as an elasto-plastic material for compression parallel to the grain (Danielsson 2013), while the bending properties of wood can show brittle or in other cases tough characteristics, depending on the wood species (Kánnár 2014).

Esteves and Pereira (2009) defined wood modification as a process that improves the properties of wood, producing a new material that does not present any environmental hazard greater than unmodified wood when disposed at the end of its product life cycle. The combined thermo-hydromechanical compression along the wood grain is a modification resulting in bendable wood. This method was previously termed "pleating" (Báder and Németh 2018). Due to the longitudinal compression, the required bending force and the modulus of elasticity decrease dramatically ensuring a high deformability of the wood material. Prior to the compression procedure, high-quality hardwood has to be plasticized by steaming. After longitudinal compression, the sample is first wet, and as long as the moisture content is on a high level (above 20\%), it can be bent easier (Báder et al. 2015). According to Báder et al. (2015), it is important to maintain an equal compression ratio along the entire length to provide consistent mechanical properties along the whole sample, which is typically ensured with the help of markings, which are tracked for all segments along the length. After that, the sample can be hold for a while in compressed state, allowing the sample to undergo viscoelastic relaxation. During relaxation, the compression stress is initially decreasing very fast and levelling out over time. In a previous study (Báder and Németh 2018), a relationship between compression stress change during relaxation, the remaining shortening and some macromechanical properties could be identified.

In the present article, the changes of mechanical properties at the micro-scale, i.e., on cell wall level, and the probable changes in the nano-scale ultrastructural arrangement at sub-cell wall level were examined. In order to determine such assumed changes, nanoindentation (NI) and atomic force microscopy (AFM) were used. NI is a relevant tool for understanding the impact of wood modification and the origin of property changes at the macroscopic scale (Eder et al. 2013). The goal of the NI measurements is to obtain the effect of the longitudinal compression and of the relaxation on the intrinsic mechanical wood cell properties at the microscale level. NI is known of being capable of measuring secondary cell wall layer S2 and was already applied in several studies involving wood substrates (Wimmer and Lucas 1997; Gindl and Schöberl 2004; Wang et al. 2006; Jäger et al. 2011; Wagner et al. 2012). It imprints a special tip (typically Berkovich type) in the selected point of the cell wall and allows for determining, besides other mechanical parameters, indentation modulus and hardness. AFM has been shown to be a useful tool for structural characterization of the cell wall on the nanoscale level (Fahlén and Salmén 2005) and has already been successfully used to monitor the microfibril arrangement with nm resolution. However, it is important to take into account that the high resolution of the AFM technique goes in line with a system-inherent lack of being representative for a bigger sample volume (Colson et al. 2016).

It is the aim of the present study to identify changes (rearrangements and fractures) occurring at the microscopic level induced by the longitudinal compression. As impact of the present work, a better understanding of the structural change and its relation to mechanical properties as a result of the longitudinally compression treatment is expected.

\section{Materials and methods}

\subsection{Sample preparation}

Both, the reference and the longitudinally compressed samples were prepared as described in detail in a previous paper (Báder and Németh 2018) and outlined as follows, as the primarily material was identical. Sessile oak wood (Quercus petraea (Matt.) Liebl.) originated from the forest of the Sopron region, Hungary. The original samples were made with a dimension of $20 \times 20 \times 200 \mathrm{~mm}^{3}$ from the same trunk and the same year ring-region of the trunk. They were first plasticized by steaming, except for the control sample (OC). A steamed control (OSC) was also made to observe a possible modifying effect of the sole steaming process. All other samples were additionally exposed to a longitudinal compression treatment inducing a 20\% deformation compared to their original length. Additional to one sample without relaxation $(\mathrm{O} 0 \mathrm{~m})$, the corresponding compression was maintained to enable relaxation for three different periods of time: $1 \mathrm{~min}(\mathrm{O} 1 \mathrm{~m}), 3 \mathrm{~min}(\mathrm{O} 3 \mathrm{~m})$ and one sample given $25 \mathrm{~h}$ for relaxation (OLm), during which the deformation was maintained. For the latter case the sample was allowed to cool down in a closed chamber, in order to not lose its moisture content. Selected general properties of the used samples are shown in Table 1. Sample preparation for nanoindentation (NI), atomic force microscopy (AFM) and scanning electron microscopy (SEM) measurements was made after the samples had been conditioned at $20{ }^{\circ} \mathrm{C}$ temperature and $65 \%$ relative humidity, resulting in about 9-10\% moisture content at the time of subsequent sample 
Table 1 Properties of individual samples used in the present study

\begin{tabular}{llllll}
\hline Treatment name & $\begin{array}{l}\text { Compression } \\
\text { ratio }(\%)\end{array}$ & $\begin{array}{l}\text { Compression stress } \\
\text { change during relaxation } \\
(\%)\end{array}$ & $\begin{array}{l}\text { Equilibrium moisture con- } \\
\text { tent after conditioning }(\%)\end{array}$ & $\begin{array}{l}\text { Remaining length change } \\
\text { after compression (\%) }\end{array}$ & $\begin{array}{l}\text { Length change during } \\
\text { the drying process }(\%)\end{array}$ \\
\hline OC & n/a & n/a & 9.9 & 0.00 & -0.08 \\
OSC & $\mathrm{n} / \mathrm{a}$ & $\mathrm{n} / \mathrm{a}$ & 9.4 & 0.00 & -0.08 \\
O0m & 20.1 & $\mathrm{n} / \mathrm{a}$ & 9.5 & -2.49 & -0.49 \\
O1m & 20.3 & -31.8 & 9.7 & -3.04 & -0.66 \\
O3m & 20.3 & -38.9 & 9.7 & -19.01 & -0.66 \\
OLm & 20.1 & -79.7 & 9.3 & -0.96 \\
\hline
\end{tabular}

OC control sample, $O S C$ steamed control sample, $O O m, O 1 m, O 3 m$ longitudinally compressed samples with 0,1 and 3 min relaxation time, $O L m$ compressed and long-time relaxed sample

preparations, whereas the moisture content at the time of the compression and relaxation treatments was consistently above the fiber saturation point.

For NI investigation, specimens with a size of approx. $2 \times 2 \times 2 \mathrm{~mm}^{3}$ were sawn out of the central part of the original samples. All of them belonged originally to the same year ring out of a latewood section. The sawn samples were embedded in epoxy resin (AGAR low viscosity resin kit, AGAR scientific, UK) by alternating vacuum treatment, paying attention to the proper alignment (Konnerth et al. 2008). The embedded epoxy blocks were cured overnight in an oven at $60{ }^{\circ} \mathrm{C}$. Parallel surfaces were cut perpendicular to the fiber orientation and glued to metal plates with a $2 \mathrm{~K}$ epoxy resin (Uhu Plus Sofortfest). Smooth surface for each specimen was prepared using a Leica Ultracut-R microtome (Leica Microsystems, Germany) equipped with a diamond knife (Trim $45^{\circ}$ and Histo, Diatome, Switzerland). These surfaces were parallel with the baseplate and smooth enough to be used in the nanoindenter. Suitable cells were selected for NI based on incident light microscopy images acquired using a Zeiss Axioplan 2 microscope (Carl Zeiss Microscopy, Germany) prior to the NI measurements. For AFM investigation, surfaces of approx. $3 \times 5 \mathrm{~mm}^{2}$ were prepared from the same year ring, exposing radially cut latewood sections. The procedure was similar to the one described for NI specimens. However, no embedding resin was used. For these specimens, a smooth surface was cut parallel to the fiber direction using an Ultra AFM diamond knife (Diatome, Switzerland) for final surfacing. For SEM investigation, approx. $5 \times 20 \mathrm{~mm}^{2}$ surfaces were prepared, with a tangential longitudinal face. Smooth surface was cut parallel to the fiber direction using a sliding microtome. Each specimen was scanned using SEM, without further preparations.

\subsection{Nanoindentation (NI)}

In the experiments, the heartwood fibres were examined from the second year ring next to the sapwood. The NI experiments, both on the cells S2 layer and on the cell corner middle lamella (CML), were performed with a Triboindenter ${ }^{\circledR}$ (Hysitron Inc, Minneapolis, USA), equipped with a Berkovich-type indenter tip. During nanoindentation experiment, ambient conditions were at $22{ }^{\circ} \mathrm{C}$ temperature and approx. 50\% relative humidity. The size of the remaining indents was selected to be in the range of one-third of the cell wall thickness. With the used settings, the resulting imprint diameters were between 1.0 and $1.6 \mu \mathrm{m}$ depending on the material properties. The cell wall thicknesses of the specimens were in the range of 3-5 $\mu \mathrm{m}$, while the dimensions of the CMLs were slightly smaller. Before and after indenting, topographic images of the measured area were acquired of each individual indentation position using scanning probe microscopy mode of the device to control for proper positioning of the indents. After the tip reached the specimen surface (using a preforce of $2 \mu \mathrm{N}$ ), a peak load of $250 \mu \mathrm{N}$ was applied in load-controlled mode within $3 \mathrm{~s}$, the force was kept constant for $20 \mathrm{~s}$, and unloading was performed within $3 \mathrm{~s}$.

From the load-depth graph the peak load $\left(P_{\max }\right)$ and the contact area at the end of the holding segment $(A)$ were extracted. Hardness $(H)$ is obtained by dividing $P_{\max }$ by $A$. The indentation modulus $\left(E_{r}\right)$ was automatically calculated according to Oliver and Pharr (1992) approach from the unloading stiffness $(S)$, which was derived from the initial slope of the unloading curve. Additional to the material stiffness, $E_{r}$ takes into account the compliance of the indenter tip. As the tested elastic modulus of wood compared to the diamond indenter tip is very small, the indenter`s influence is assumed to be negligible (Konnerth and Gindl 2006) and was not further corrected. This approach was considered to be feasible as shown in various other studies (Gindl and Schöberl 2004; Tze et al. 2007; Wagner et al. 2012; Eder et al. 2013; Zhou et al. 2017). It has to be considered that in contrast to isotropic materials for the case of the anisotropic wood cell wall, $E_{r}$ cannot be attributed to a single uniaxial modulus (Jäger et al. 2011). Since the results for $E_{r}$ are derived from the same and thus comparable base material (same tree, the same height in the trunk and from the same 
year ring), a relative comparison of modulus values between the specimens is considered to be meaningful. The ratio of $H$ to $E_{r}$ is defined as the indentation plastic yield resistance (Oyen and Cook 2009), whereby the physical meaning of a large value is that the yield stress of the material is large, relative to the modulus, so that plastic deformation by indentation is difficult. For coatings, this involves a relation to wear resistance of a surface (Skarmoutsou et al. 2013).

A typical individual load-depth curve is shown in Fig. 1. The total deformation work by indentation $\left(W_{t}\right)$ is computed numerically, summarizing the multiplications of the indentation depth change $(\Delta h)$ for a time unit and the measured load $(P)$ for the corresponding time unit. As the time unit was set to $0.017 \mathrm{~s}$ (corresponding to the time, force, and depth measurement signal frequency), a sufficiently accurate calculation of deformation work was obtained. The area under the load-displacement graph (Fig. 1) is $W_{t}$ and it can be subdivided into three parts as shown in earlier applications (Konnerth et al. 2006), namely plastic deformation work $\left(W_{p}\right)$, viscoelastic deformation work $\left(W_{v}\right)$ and elastic deformation work $\left(W_{e}\right)$ as shown in Fig. 1. $W_{v}$ (Fig. 1) gives similar information about the material to indentation creep $\left(C_{I T}\right) . C_{I T}$ is calculated as a relative change of the indentation depth during the segment of constant load and frequently used to indicate comparable material properties by other authors (Wang et al. 2006; Jha et al. 2012; Eder et al. 2013).

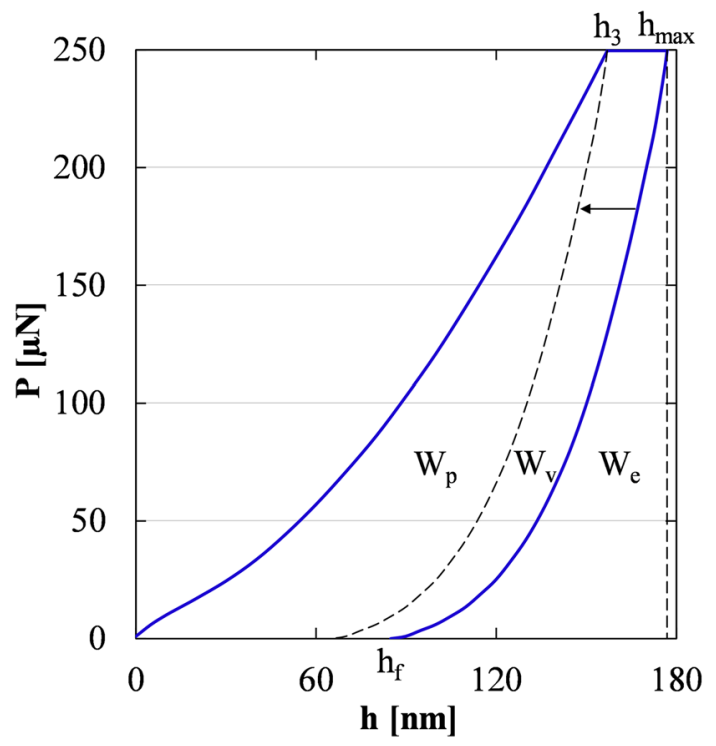

Fig. 1 A typical nanoindentation load-depth curve for a compressed and long-time relaxed specimen. The areas of the different deformation work phases are indicated between the borderlines. $W_{p}$ plastic deformation work, $W_{v}$ viscoelastic deformation work, $W_{e}$ elastic deformation work, $h_{3}$ indentation depth at the beginning of the holding segment, $h_{\max }$ maximal indentation depth, $h_{f}$ residual indentation depth
When the wood material is subjected to a constant force for a period of time, a time-dependent deformation occurs, visible in Fig. 1 between the points of $h_{3}$ and $h_{\max }$. The maximal indentation depth $\left(h_{\max }\right)$ is reached at the end of the holding segment, then the deforming force is released and the deformed imprint partly recovers. Final or residual indentation depth $\left(h_{f}\right)$-also called elastic recovery depthindicates additionally the remaining deformation (viscoelastic, plastic deformation) of the material (Oliver and Pharr 1992). $W_{e}$ provides information about the elastic property of the cell walls similar to the difference of $h_{\max }$ and $h_{f}$, which is used by other authors, for example Richter et al. (2000). By comparing the parameters described above, a quantitative comparison of the material behavior as a result of longitudinal compression can be performed. For the NI experiments, the TriboScan v8.2.0.18 (Hysitron Inc, Minneapolis, USA) software was used.

\subsection{Atomic force microscopy}

The ultrastructural characterization was made with a Dimension Icon AFM using ScanAsyst-Air cantilevers (both Bruker, Santa Barbara, CA, USA) using Bruker's ScanAsyst mode in air. A scan rate of $0.5 \mathrm{~Hz}$ was used, and the size of the generated images was $5 \times 5 \mu \mathrm{m}^{2}$ at a resolution of $512 \times 512$ pixels. Gain factors and amplitude settings were the same for all applied scans. The data was exported from the measurement software (Nanoscope Analysis) to the output files, which were further processed using free Gwyddion 2.48 software (http://gwyddion.net). For visibility reasons, the image contrast was optimized posteriorly using free IrfanView 4.38 software.

\subsection{Scanning electron microscopy}

The microscopic images were obtained with a scanning electron microscope (Hitachi S-3400N, Tokyo, Japan). During imaging, the specimen was in a vacuum of $6 \mathrm{kPa}$, and the accelerating voltage of the electron beam was set to $10 \mathrm{kV}$. After finding the right position and magnification, automatic contrast, brightness and focus were selected with the software of the microscope. Then the image was taken with a resolution of $2560 \times 1920$ pixels. The version of the used Hitachi software was 1.24 (serial number: 340632-01). Later the image contrast and gamma were optimized using free IrfanView 4.38 software.

\subsection{Statistical analysis}

The statistical analysis was performed using Dell Statistica version 13 software. A one-way analysis of variance (ANOVA) Fisher LSD test with probabilities for post hoc tests was used for comparative analyses of hardness, 
indentation modulus and deformation work of the different treatments. The differences were marked as significant at $\mathrm{p}<0.05$. Statistical analysis of the differences among all the treatment groups was made using $\mathrm{T}$ test and the variables were treated as independent specimens.

\section{Results and discussion}

Macromechanical experiments with the same wood material and the same longitudinal compressions were already reported in a previous study (Báder and Németh 2018). In order to show the significant differences of the macromechanical properties as a result of the various treatments, corresponding values are listed in Table 2. Modulus of rupture $(M o R)$ and modulus of elasticity $(M o E)$ were tested in 4-point bending mode using samples conditioned at $20{ }^{\circ} \mathrm{C}$ temperature and $65 \%$ relative humidity.

As a result of the longitudinal compression treatment, already at the macroscopic scale, a significant increase in the maximum deflection with increasing relaxation time is evident. This high deformability comes along with a significant decrease in $M o E$ together with a decrease in $M o R$. It is worth to note that during the 4-point bending tests, the OLm samples could not be brought to rupture, thus the inherent maximal deflection of this sample type was at least $675 \%$, but could not be determined exactly.

\subsection{Nanoindentation}

In the box and whiskers plots presented in Fig. 2, the mechanical properties indentation hardness $(H)$ and indentation modulus $\left(E_{r}\right)$ are presented for the control group and the different treatment methods. The results indicated represent 60-94 measurements per specimen group.

Steaming slightly increased the values of $H$. The longitudinal compression treatments resulted in a decrease in
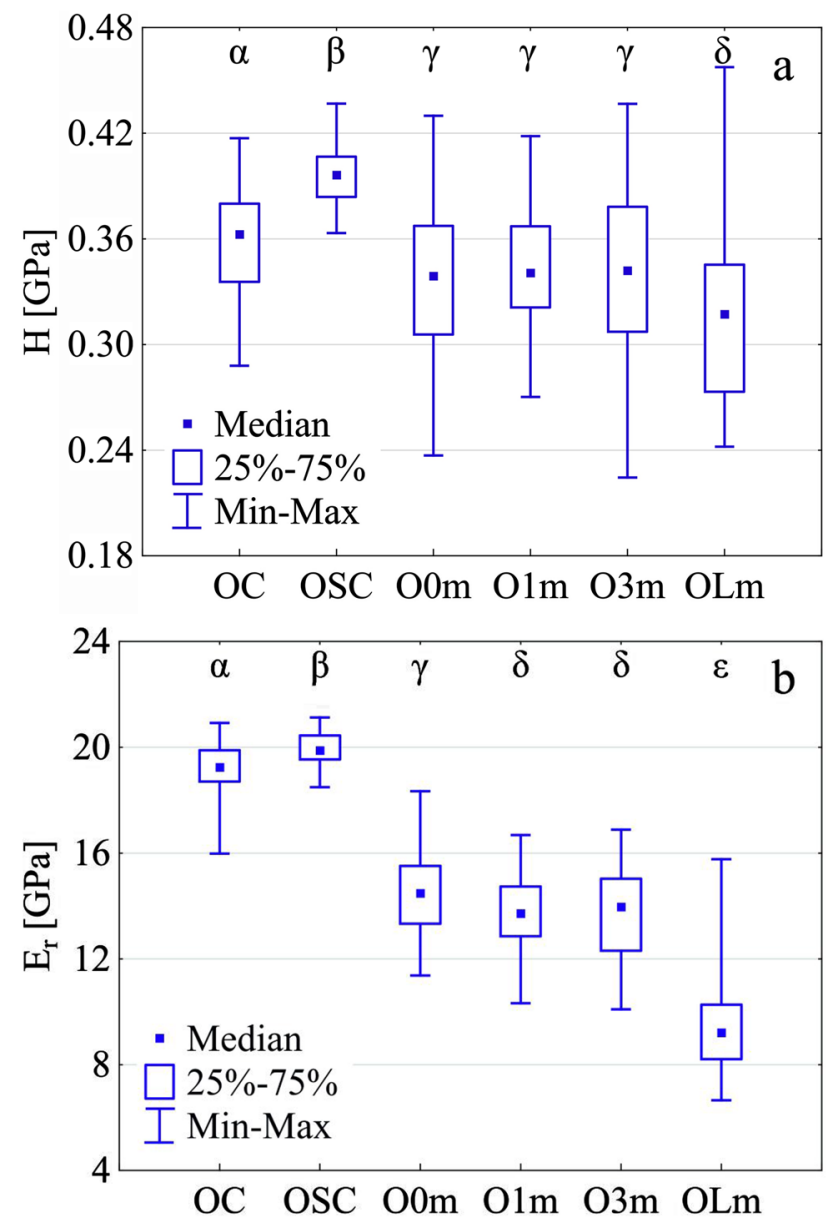

Fig. 2 Oak cell wall hardness (a) and indentation modulus (b). Statistically homogeneous groups identified by ANOVA are denoted with Greek letters. Box plots indicate medians, the quartiles and the minimum and maximum values. $O C$ control specimen, $O S C$ steamed control specimen, $O 0 \mathrm{~m}, \mathrm{Olm}, \mathrm{O} 3 \mathrm{~m}$ longitudinally compressed specimens with 0,1 and 3 min relaxation time, OLm compressed and long-time relaxed specimen

Table 2 Influence of longitudinal compression and different relaxation times on the mechanical properties of oak, average values (based on Báder and Németh 2018)

\begin{tabular}{|c|c|c|c|c|c|c|}
\hline Treatment name & $\begin{array}{l}\text { Compression } \\
\text { ratio }(\%)\end{array}$ & $\begin{array}{l}\text { Remaining length change } \\
\text { after conditioning }(\%)\end{array}$ & MoR (MPa) & $\operatorname{MoE}(\mathrm{GPa})$ & $\begin{array}{l}\text { Deflection at maxi- } \\
\text { mum load }(\%)\end{array}$ & $\begin{array}{l}\text { Maximum } \\
\text { deflection } \\
(\%)\end{array}$ \\
\hline OC & 0.0 & -0.1 & 110.4 & 10.0 & 100 & 100 \\
\hline OSC & 0.0 & -0.1 & 112.8 & 10.1 & 104 & 104 \\
\hline $\mathrm{O} 0 \mathrm{~m}$ & 20.3 & -3.7 & 106.9 & 4.2 & 298 & 319 \\
\hline $\mathrm{O} 1 \mathrm{~m}$ & 20.3 & -4.3 & 105.3 & 3.7 & 330 & 353 \\
\hline $\mathrm{O} 3 \mathrm{~m}$ & 20.3 & -4.7 & 103.7 & 3.4 & 364 & 396 \\
\hline $\mathrm{O} 5 \mathrm{~m}$ & 20.3 & -5.1 & 102.7 & 3.2 & 343 & 364 \\
\hline OLm & 20.0 & -16.6 & 53.5 & 1.9 & 370 & $675+$ \\
\hline
\end{tabular}

$O C$ control sample, $O S C$ steamed control sample, $O O m, O 1 m, O 3 m, O 5 m$ longitudinally compressed samples with $0,1,3$ and 5 min relaxation time, $O L m$ compressed and long-time relaxed sample 
$H$ by $6 \%$, while $E_{r}$ decreased by $25 \%$ compared to the OC specimens. After $1 \mathrm{~min}$, relaxation $E_{r}$ decreased to $28 \%$, but did not further decrease by the 3 min relaxation. Specimens exposed to the long-time relaxation showed further changes in $H$ and $E_{r}$ values, resulting in losses compared to OC specimens of $12 \%$ and $51 \%$, respectively. This means that after a long relaxation time, $E_{r}$ was reduced at least to half of its original value and this is considered to be most important for the bendability of the material. Comparing hardness and indentation moduli (Fig. 2a, b), the graphs show a similar tendency, whereby indentation modulus values were significantly more affected by the treatment compared to hardness values.

Statistical analyses could not reveal significant differences between the different short treatment times $\mathrm{O} 0 \mathrm{~m}-\mathrm{O} 1 \mathrm{~m}-\mathrm{O} 3 \mathrm{~m}$ for $H$, and $\mathrm{O} 1 \mathrm{~m}-\mathrm{O} 3 \mathrm{~m}$ for $E_{r}$ at microscopic scale. Between $\mathrm{O} 0 \mathrm{~m}-\mathrm{O} 1 \mathrm{~m}$ for $\mathrm{E}_{\mathrm{r}}$ a slight but significant decrease could be observed. However, macromechanical properties (for example $M o E$ ) showed much higher changes for most parameters (Table 2). When comparing macromechanical properties ( $M o E$ and maximal deflection) with the observations made at microscopic scale $(H$ and $\left.E_{r}\right)$, similar trends can be found. Short-time relaxations result in less pronounced changes in the cell wall compared to the long-time relaxation treatment. Regarding absolute values, the decrease in $M o E$ after compression and 1 min relaxation is $63 \%$ compared to the original value of untreated oak, while the decrease in $E_{r}$ is $28 \%$ only. The micromechanical characterization of the longitudinally compressed wood shows similar tendency to the uniaxial results determined on macroscale level, but to a less pronounced extent. This finding is not surprising as $E_{r}$ reflects the material parameters of the full stiffness tensor components of the orthotropic wood cell wall (Jäger et al. 2011) in contrast to the uniaxially determined macromechanical properties, which represent one material direction only.
Based on the macromechanical results and economic rationale, a relaxation time of $1 \mathrm{~min}$ was recommended (Báder and Németh 2018). At that time, significant changes in mechanical properties have already been reached. For achieving further modification by a comparable magnitude, significantly higher amount of time (in this case it was $25 \mathrm{~h}$ ) is needed. Some kind of change of the wood cell structure within the secondary cell wall S2 can be adumbrated from cell cross sections displayed in Fig. 3a-c, visible in higher roughness and some kind of wrinkles appearing within the secondary cell wall $\mathrm{S} 2$ for specimens with increased relaxation time. This change is attributed to local fibril deviations. As the image was acquired with a Bercovich tip that allows limited local resolution only, these features may also derive from other small features, such as cracks, but this is regarded as rather unlikely. The lumina of all investigated cells displayed in Fig. 3a-c were filled with an embedding resin prior to preparing the specimen surfaces. After re-conditioning the specimens, the cell walls slightly swelled. This caused the differences in height within the cell wall and furthermore between the cell wall and the embedding resin (Fig. 3a). As all specimens got the same surface treatment during specimen preparation with the same accessories, this nanometer scale difference-called wrinkles-in roughness within the cell wall is assumed to be a result of different response of the material to surface exposure. The reason may be a local deviation from the typical fibril alignment within the cell wall and consequently local differences in longitudinal swelling of cell wall areas with respect to the cell axis as a result of slight climatic changes occurring between specimen preparation and measurement.

From the cross sectional analyses, it is assumed that initially the change of the cell structure is only local, and effects a wider cross sectional area for longer relaxation time. The increase in surface roughness possibly contributes to the high scattering of results displayed in Fig. 2a, b, as only for specimens exposed to short-time relaxation treatment
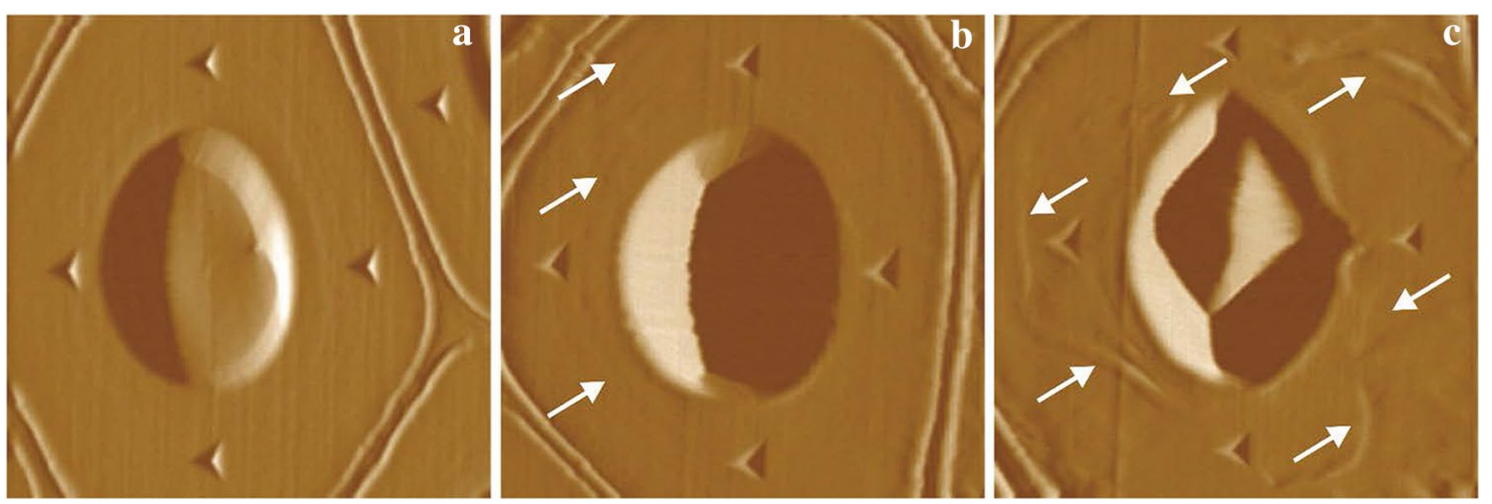

Fig. 3 Scanning probe microscopy gradient images acquired with the indenter tip, showing $15 \times 15 \mu \mathrm{m}$ sections: control specimen (a), compressed specimen without relaxation (b), compressed specimen with a long-time relaxation $(\mathbf{c})$. The arrows indicate wrinkles on the cell wall 
Table 3 Calculated results from the nanoindentation data

\begin{tabular}{llrl}
\hline & $\mathrm{H} / \mathrm{E}_{\mathrm{r}}\left(\times 10^{3}\right)$ & $\mathrm{W}_{\mathrm{t}}(\%)$ & $\begin{array}{l}\text { Statistical } \\
\text { signifi- } \\
\text { cance }\end{array}$ \\
\hline OC & 18.6 & 100.0 & $\alpha$ \\
OSC & 19.8 & 95.3 & $\beta$ \\
O0m & 23.3 & 106.5 & $\gamma$ \\
O1m & 24.8 & 106.3 & $\gamma$ \\
O3m & 24.9 & 106.9 & $\gamma$ \\
OLm & 33.4 & 113.5 & $\delta$ \\
\hline
\end{tabular}

Statistically homogeneous groups identified by ANOVA are denoted with Greek letters

OC control specimen, $O S C$ steamed control specimen, $O 0 m, O 1 m$, $\mathrm{O} 3 \mathrm{~m}$ longitudinally compressed specimens with 0,1 and $3 \mathrm{~min}$ relaxation time, OLm compressed and long-time relaxed specimen, $H$ indentation hardness, $E_{r}$ indentation modulus, $W_{t}$ total indentation work

smooth surface regions can be found for the indentation, while those areas became scarce for specimens exposed to long-time relaxation.

As mentioned above, the $H / E_{r}$ ratio is a parameter indicating the indentation plastic yield resistance. Due to the compression procedure with short relaxation times, the $H / E_{r}$ ratio increased already considerably by $25 \%$, the long-time relaxation treatment increases the indentation plastic yield resistance even more, with about $80 \%$ increase (Table 3). For surfaces, for example coatings, this parameter is related to wear, which could imply that the present wood modification procedure could result in improved mechanical wear resistance of the cells, hence in improved wear resistance of the cross section of wood. The increase in maximal indentation depth as well as the increase in the resulting parameter $W_{t}$ (Table 3) is again well in line with changes of the material's mechanical properties along with the degree of modification. Statistical analyses could not reveal significant differences between the different short treatment times $\mathrm{O} 0 \mathrm{~m}-\mathrm{O} 1 \mathrm{~m}-\mathrm{O} 3 \mathrm{~m}$ both for $H / E_{r}$ and different types of work $\left(W_{t}, W_{p}, W_{v}, W_{e}\right)$.

As the material behavior of the cell cannot be described sufficiently by a single elastic parameter $\left(E_{r}\right)$, the deformation work spent during indentation was analyzed in addition and was subdivided into its plastic $\left(W_{p}\right)$, viscoelastic $\left(W_{v}\right)$ and elastic $\left(W_{e}\right)$ deformation work components, as shown in Fig. 1. This way the different types of deformation work occurring during indentation and their changes can be compared as shown in Fig. 4 by analyzing the ratio of the indentation work types for each treatment. The differences in total work of deformation are displayed in Table 3.

The relative amount of elastic deformation work increases by both compression (3\%) and long-time relaxation (9\%), i.e., the mechanical properties of the cell wall material is shifting towards a higher amount of elasticity with the

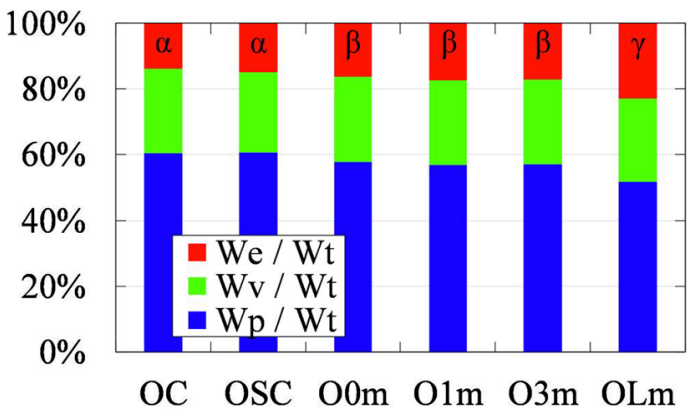

Fig. 4 Relative indentation work for the performed treatments. Groups identified by ANOVA, where all relative indentation works statistically homogeneous are denoted with Greek letters. $O C$ control specimen, $O S C$ steamed control specimen, $O O m, O 1 m, O 3 m$ longitudinally compressed specimens with 0,1 and 3 min relaxation time, $O L m$ compressed and long-time relaxed specimen, $W_{t}$ total indentation work, $W_{p}$ plastic deformation work, $W_{v}$ viscoelastic deformation work, $W_{e}$ elastic deformation work

long-time relaxation treatment method. This increase in elastic deformation work occurred at the expense of the plastic deformation work of the material, which decreased by both, the longitudinal compression (3\%) and the long-time relaxation (9\%) (Fig. 4). The ratio between the two deformation works $W_{e} / W_{p}$ increased from 23 to $44 \%$ in the case of long-time relaxation treatments. This means higher resilience (elastic deformation work) and lower ductility (plastic deformation work) on the cell wall level. This finding seems to contradict previously reported observations (Báder and Németh 2018) made on macroscopic scale. There, the dramatically increased maximum deflection comes along with significantly increased ductility of the bulk specimens when treated with long-time relaxation. Regarding the value of the viscoelastic deformation work $\left(W_{v}\right)$, no considerable changes were evident, and the difference between control and treated specimens was statistically insignificant. $W_{v}$ is a measure for the time-dependent deformation behavior and was monitored at constant load. The viscoelastic behavior of the cell walls remains unaffected by the treatments.

In addition to the mechanical data of the secondary cell wall S2, which is decisive for the mechanical properties of the wood structure, changes occurring in the cell corner middle lamella (CML) were also investigated. The results indicated represent eleven measurements in OC and OLm specimen groups. The same amount of $\mathrm{S} 2$ cell wall layer measurement near to the CML measurement places were chosen to compare the averages of the two tissue elements. The proportional changes between the specified properties of control and modified specimens with long relaxation time, both for CML and secondary cell wall S2, were compared (Table 4).

Table 4 shows that changes of most mechanical properties as a result of the treatment are much lower in case of 
Table 4 Ratio of mechanical property changes of compressed and long-time relaxed (OLm) to control (OC) specimens for both, secondary cell wall layer (S2) and for cell corner middle lamella (CML)

\begin{tabular}{lrrrrrr}
\hline & $\mathrm{H}(\%)$ & $\mathrm{E}_{\mathrm{r}}(\%)$ & $\mathrm{W}_{\mathrm{t}}(\%)$ & $\mathrm{W}_{\mathrm{e}}(\%)$ & $\mathrm{W}_{\mathrm{v}}(\%)$ & $\mathrm{W}_{\mathrm{p}}(\%)$ \\
\hline OLm/OC ratio of S2 & -12.9 & -47.9 & 13.8 & 8.6 & 0.2 & -8.7 \\
OLm/OC ratio of CML & 1.5 & -19.0 & -1.2 & 6.1 & -2.1 & -4.1 \\
\hline
\end{tabular}

$H$ indentation hardness, $E_{r}$ indentation modulus, $W_{t}$ total indentation work, $W_{e}$ elastic deformation work, $W_{v}$ viscoelastic deformation work, $W_{p}$ plastic deformation work

CML than in case of $\mathrm{S} 2$, but are still considerable for the case of $E_{r}$. Hardness, total deformation work and viscoelastic deformation work of CML did not change noticeably in CML. The ratio of $W_{e} / W_{p}$ increased from 24 to $45 \%$ for the case of long-time relaxation treatments tested on S2 cell layers. For the case of $\mathrm{CML}, W_{e} / W_{p}$ ratio changed from 60 to $81 \%$. Thus, it can be stated, that both cell layers S2 and CML change towards higher elasticity. The difference between S2 and CML may be attributed to their chemical composition and structural arrangement of the two cell layers. The comparable homogeneous composition of the CML is opposing to the highly anisotropic S2 layer. As a result of the treatment, the fibril arrangement of the S2 layer may be significantly disturbed. Similar structural changes in CML are less likely to occur due to the lack of highly oriented microfibrils. The property changes of CML indicate some mechanical changes, namely the weakening of the middle lamella, which aids to the structural integrity needed for bending of wood. Additionally, the reduction in fiber length as well as the change of the properties of CML as a result of the compression treatment are assumed to contribute to the overall mechanical behaviour of the material.

\subsection{Atomic force microscopy (AFM)}

In order to visualize microfibril orientation, topographical information was acquired using AFM on longitudinal sections of specimens. This way the AFM equipment was used to characterize the local microfibril orientation in order to compare the control specimens with the longitudinally compressed specimens on their ultrastructural level. The AFM peak force error (PFE) channel is a derivative of topography in the scan direction (Heu et al. 2012). The analysis of the PFE images seemed the best for the visualization of the fibril arrangement. The microfibrils appear straight and parallel to each other at the control specimen (Fig. 5a), similar to what is expected as normal orientation in wood cell walls. For the longitudinally compressed and long-time relaxed specimen (Fig. 5b), clear fibril deviation is visible, which may be described as crinkles with wavelike shape. The parallel alignment of the microfibrils is still visible, but the microfibrils change their direction from crinkle to crinkle.
For AFM investigations, the surfaces were cut parallel to the fiber direction, and in Fig. 5b it is assumed that due to the disorientation of the microfibrils those are often intersected. Despite of the fact that only 2D orientation is visible in Fig. 5 it is expected that crinkling arises in 3D. As can be seen in Fig. 5, the S2 layer is a highly aligned and ordered orthotropic material in untreated conditions. The misalignment of the fibrils after treatment - as evident in the $S 2$ cell wall layer-is attributed to cause the previously described dramatic reduction of $E_{r}$ and $M o E$. In contrast, ML is mainly consisting of lignin, with assumed isotropic material behavior (Gindl and Schöberl 2004), thus this phenomenon in ML does not exist to a similar extent as already observed at the differences in mechanical behavior between S2 and ML.

Examining the SEM images shown in Fig. 6, again crinkled parts appear at every longitudinally compressed wood cell as well as at the trachea. The effect was again most pronounced for the long-time relaxed specimens. On the upper side of the image, twisted and crushed cell lumens can be seen, while in the center of the image, a large trachea tube is visible that is corrugated along its full length. The lumens of cells often fully disappear, and the thin wall of the trachea often diverges from the encircling parts of the wood. Because the appearance is similar to a plisse shade on both length scales, the naming "pleated wood" is proposed for longitudinally compressed wood (Báder and Németh 2018).

Although between the AFM and SEM images is an order of magnitude difference in scale, the disorientation of the cells and vessels wall parts visible in Fig. 6 is present in the microfibril level as well. Even though AFM images (Fig. 5b) show a very small specimen surface only, it is assumed that the observed effect is representative of the whole sample and this way for all pleated wood.

When comparing the mechanical properties with the observed structural changes due to the hydro-thermomechanical treatment, the remarkable decrease in $M o E$ by longitudinal compression and the remarkable decrease in compression stress by relaxation can be well explained by the systematically deformed fibers. On the ultrastructural level, the disoriented microfibrils go along with the reduced $E_{r}$ value. The latter finding on the cell wall level again well explains the dramatic changes in micromechanical properties assessed by NI, as the significant influence of the local 
Fig. 5 AFM peak force error images of radial sections of oak wood double cell walls showing middle lamella (ML), primary cell wall $(\mathrm{P})$, secondary cell walls (S1 and S2) and corresponding microfibril orientation. Control specimen (a) and a compressed specimen exposed to $25 \mathrm{~h}$ relaxation time $(\mathbf{b})$. The arrows indicate the microfibril direction in the S2 layer. $M L$ middle lamella, $S 1$ outer layer of the secondary wall, $S 2$ middle layer of the secondary wall
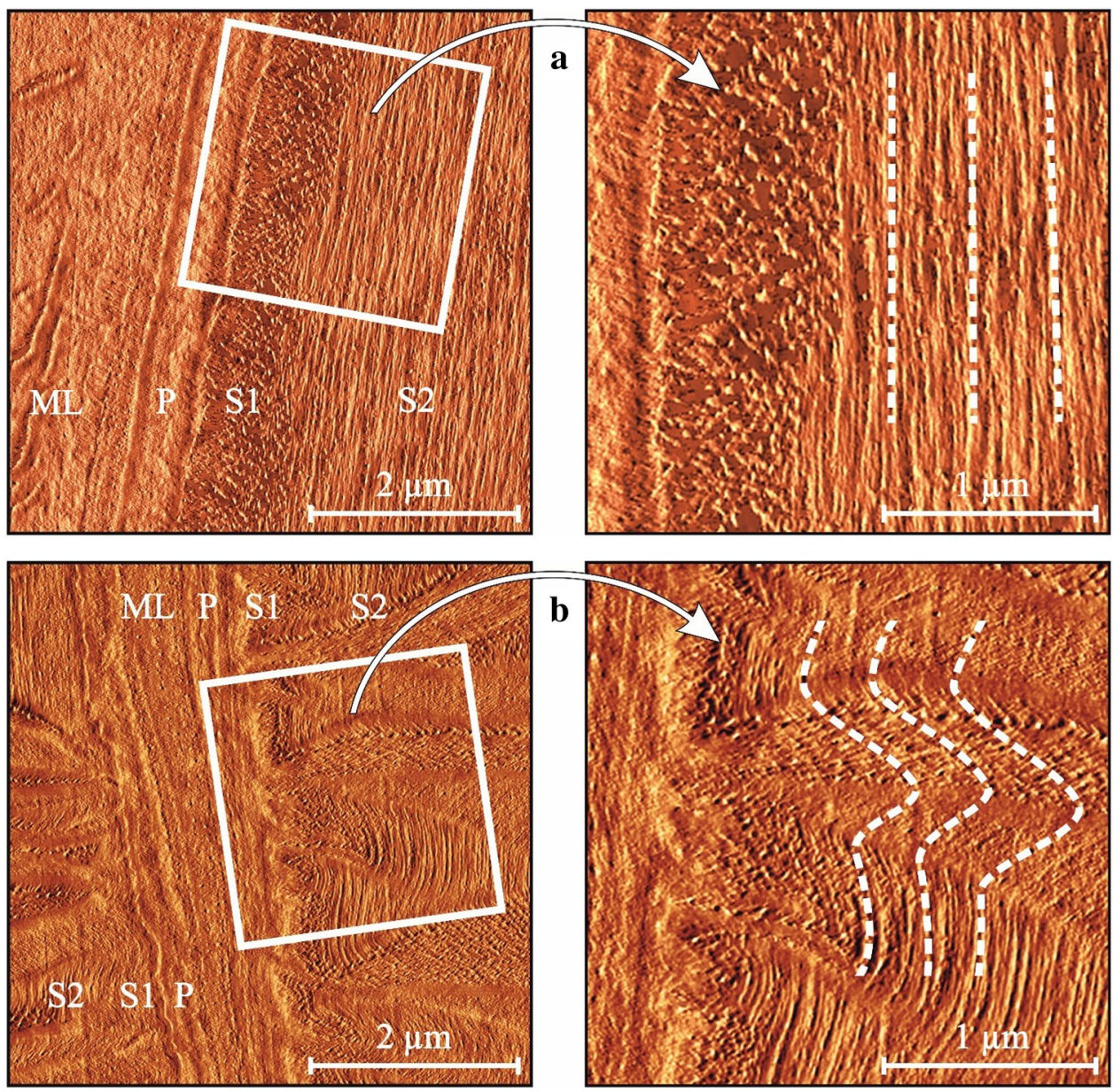

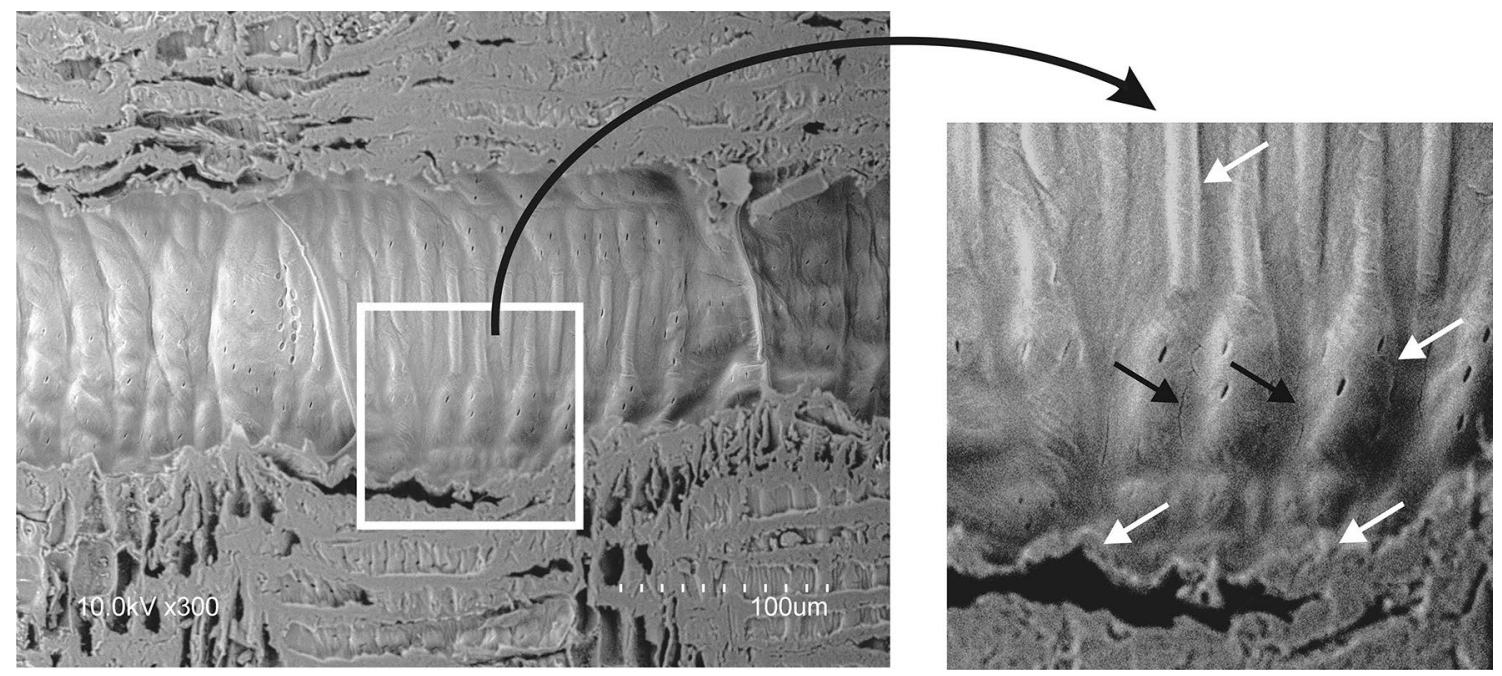

Fig. 6 Scanning electron microscopy image of oak wood, showing in magnification $\times 300$, crinkles in a trachea due to the longitudinal compression and $25 \mathrm{~h}$ relaxation process, and an enlarged part of the trachea's buckled wall. White arrows indicate some crinkles, black arrows indicate small cracks on the inner lumen wall of the trachea 
microfibril angle on those properties is a well-known fact (Jäger et al. 2011; Gindl and Schöberl 2004). When it comes to deformation work, results seem to be less clear. At the cell wall level, work of plastic deformation is reduced at the expense of elastic deformation work when long-time compression treatment is applied. In contrast, long-time treatment results in higher ductility on the macroscopic level. Despite of the changes towards lower ductility of the cell wall itself, an unfolding or stretching of the fibers at a scale visible in Fig. 6 might superimpose the micromechanical behavior and thus account for the significantly increased ductility at the macroscopic scale.

\section{Conclusion}

With the present research, micromechanical characterization of longitudinally compressed wood could be successfully compared to untreated reference materials. The comparison of the various methods of treatments showed that the indentation modulus of the secondary cell wall S2 significantly decreased as a result of the compression and relaxation treatments, whereas the hardness of the $\mathrm{S} 2$ cell wall was only slightly affected. Total deformation work of cell walls increased when wood was treated. Relative to the total deformation work, its viscoelastic share remained unchanged, while elastic behavior was increased at the expense of plastic deformation work. Thus, the treatments resulted in higher flexibility together with higher resilience and reduced ductility on the cell wall level, compared to the untreated wood. Comparing indentation modulus with macromechanical properties, the observable degree of change was smaller, which was attributed to the difference in stress state of the two methods. As a general trend, higher relaxation time increased the effects of the longitudinal compression treatment.

In contrast to the $\mathrm{S} 2$, the cell wall middle lamella was only subjected to minor changes as a result of the treatments. AFM images showed microfibril disorientation in the $\mathrm{S} 2$ cell wall due to mechanical wood modification. Similar observations were also made on the cellular level. Therefore, the earlier proposed term "pleating" seems to well describe the treatment.

Acknowledgements Open access funding provided by University of Sopron (SOE). The described work was carried out as part of the "Production with nature-Agroforestry as a new perspective", EFOP3.6.2-16-2017-00018 project in the framework of the Széchenyi2020 Program. The realization of this project is supported by the European Union, co-financed by the European Social Fund. The authors graciously thank European Cooperation in Science and Technology (COST) Action FP1407 STSM (Grant number: 121016-080657) for the travel funding and support. The authors would like to acknowledge the helpful assistance for specimen preparation and AFM measurements of Sabine Herzele and Jerome Colson, BOKU University Vienna, Tulln.

\section{Compliance with ethical standards}

Conflict of interest On behalf of all authors, the corresponding author states that there is no conflict of interest, related to this manuscript.

OpenAccess This article is distributed under the terms of the Creative Commons Attribution 4.0 International License (http://creativeco mmons.org/licenses/by/4.0/), which permits unrestricted use, distribution, and reproduction in any medium, provided you give appropriate credit to the original author(s) and the source, provide a link to the Creative Commons license, and indicate if changes were made.

\section{References}

Ashby MF (2005) Materials selection in mechanical design, 3rd edn. Butterworth-Heinemann, Oxford

Báder M, Németh R (2018) The effect of the relaxation time on the mechanical properties of longitudinally compressed wood. Wood Res 63(3):383-398

Báder M, Németh R, Ábrahám J (2015) Faanyag rostirányú tömörítésével kapcsolatos elméleti és gyakorlati kérdések áttekintése. II. rész: Történelem és szabadalmak. A tömörítési folyamat tulajdonságai és a tömörítést követő eljárások. (Practical issues of longitudinally compressed wood. Part 2 : history and patents. Properties of the compression process, and the procedures after compression) (in Hungarian). Faipar 63(1):10-20

Butterfield BG, Meylan BA, Peszlen IM (1997) Three dimensional structure of wood. Hillebrand Press, Sopron

Colson J, Bauer W, Mayr M, Fischer W, Gindl-Altmutter W (2016) Morphology and rheology of cellulose nanofibrils derived from mixtures of pulp fibres and papermaking fines. Cellulose 23(4):2439-2448

Danielsson H (2013) Perpendicular to grain fracture analysis of wooden structural elements. PhD Dissertation, Lund University, Sweden

Dinwoodie JM (1971) Wood. Composites 2(3):170-172

Eder M, Arnould O, Dunlop JWC, Hornatowska J, Salmén L (2013) Experimental micromechanical characterisation of wood cell walls. Wood Sci Technol 47:163-182

Esteves BM, Pereira HM (2009) Wood modification by heat treatment: a review. BioRes 4(1):370-404

Fahlén J, Salmén L (2005) Pore and matrix distribution in the fiber wall revealed by atomic force microscopy and image analysis. Biomacromolecules 6:433-438

Fratzl P, Weinkamer R (2007) Nature's hierarchical materials. Prog Mater Sci 52:1263-1334

Gindl W, Schöberl T (2004) The significance of the elastic modulus of wood cell walls obtained from nanoindentation measurements. Compos Part A 35:1345-1349

Heu C, Berquand A, Elie-Caille C, Nicod L (2012) Glyphosate-induced stiffening of HaCaT keratinocytes, a peak force tapping study on living cells. J Struct Biol 178:1-7

Jäger A, Hofstetter K, Buksnowitz C, Gindl-Altmutter W, Konnerth J (2011) Identification of stiffness tensor components of wood cell walls by means of nanoindentation. Compos Part A 42:2101-2109

Jha KK, Suksawang N, Lahiri D, Agarwal A (2012) Energy-based analysis of nanoindentation curves for cementitious materials. ACI Mater J 109(1):81-90 
Kánnár A (2014) A faanyag makro- és mikro-tönkremeneteli folyamatai (The micro- and macro-failures processes of wood) (in Hungarian). Palatia Press, Győr

Konnerth J, Gindl W (2006) Mechanical characterisation of woodadhesive interphase cell walls by nanoindentation. Holzforsch 60:430-431

Konnerth J, Jäger A, Eberhardsteiner J, Müller U, Gindl W (2006) Elastic properties of adhesive polymers. II. Polymer films and bond lines by means of nanoindentation. J Appl Polim Sci 102:1234-1239

Konnerth J, Harper D, Lee S-H, Rials TG, Gindl W (2008) Adhesive penetration of wood cell walls investigated by scanning thermal microscopy (SThM). Holzforsch 62:91-98

Matti P (2014) Ductility of wood and wood members connected with mechanical fasteners. Master's thesis, Aalto University, Finland

Niemz P (1993) Physik des Holzes und der Holzwerkstoffe (Physics of wood and wood-based products) (in German). DRW-Verlag, Leinfelden-Echterdingen

Oliver WC, Pharr GM (1992) An improved technique for determining hardness and elastic modulus using load and displacement sensing indentation experiments. J Mater Res 7:1564-1583

Oyen ML, Cook RF (2009) A practical guide for analysis of nanoindentation data. J Mech Behav Biomed Mater 2:396-407

Richter A, Ries R, Smith R, Henkel M, Wolf B (2000) Nanoindentation of diamond, graphite and fullerene films. Diam Relat Mater 9:170-184

Silva AD, Kyriakides S (2007) Compressive response and failure of balsa wood. Int J Solids Struct 44:8685-8717

Skarmoutsou A, Lolas G, Charitidis CA, Chatzinikolaidou M, Vamvakaki M, Farsari M (2013) Nanomechanical properties of hybrid coatings for bone tissue engineering. J Mech Behav Biomed Mater $25: 48-62$
Tamer AT, Fauziah AA (2013) Cellulose microfibril angle in wood and its dynamic mechanical significance. In: van De Ven T, Godbout L (eds) Cellulose-fundamental aspects. InTech, Rijeka, pp 113-142

Tze WTY, Wang S, Rials TG, Pharr GM, Kelley SS (2007) Nanoindentation of wood cell walls: continuous stiffness and hardness measurements. Compos A 38:945-953

Wagner L, Bader TK, de Borst K, Eberhardsteiner J (2012) Nanoindentation to study within-tree variability of wood cell wall stiffness. In: Ognjanovic M (ed) Proceedings of the 29th Danubia-Adria symposium on experimental mechanics, University of Belgrade, Serbia, pp 8-9

Wang S, Lee S-H, Tze WTY, Rials T, Pharr GM (2006) Nanoindentation as a tool for understanding nano-mechanical properties of wood cell wall and biocomposites. In: Proceedings of international conference on nanotechnology for the forest products industry, Marriott Marquis, Atlanta, Georgia, USA, pp 152-158

Wimmer R, Lucas BN (1997) Comparing mechanical properties of secondary wall and cell corner middle lamella in spruce wood. IAWA J 18:77-88

Zhou X, Wang Y, Wang L, Lv J, Zhao R, Yao L, Chen Z (2017) Cell wall structure and mechanical properties of Salix Psammophila. Wood Res 62(1):01-12

Publisher's Note Springer Nature remains neutral with regard to jurisdictional claims in published maps and institutional affiliations. 